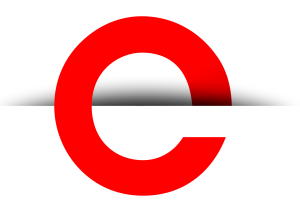

U T S

e PRES S
PORTAL Journal of Multidisciplinary International Studies

Vol. 17, No. 1/2

Jan 2021

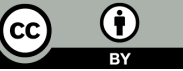

(C) 2021 by the author(s). This is an Open Access article distributed under the terms of the Creative Commons Attribution 4.0 International (CC BY 4.0) License (https:// creativecommons.org/ licenses/by/4.0/), allowing third parties to copy and redistribute the material in any medium or format and to remix, transform, and build upon the material for any purpose, even commercially, provided the original work is properly cited and states its license.

Citation: Brown, A. 2021. Transnational Memory and the Fukushima Disaster:

Memories of Japan in

Australian Anti-nuclear Activism. PORTAL Journal of Multidisciplinary International Studies, 17:1/2, 136-151. http://dx.doi.org/10.5130/ pjmis.v17i1-2.7094

ISSN 1449-2490 | Published by UTS ePRESS I http://epress. lib.uts.edu.au/ojs/index.php/ portal
GENERAL ARTICLE (PEER REVIEWED)

\section{Transnational Memory and the Fukushima Disaster: Memories of Japan in Australian Anti-nuclear Activism}

\author{
Alexander Brown \\ Corresponding author: Dr Alexander Brown, JSPS International Research Fellow, Department \\ of Studies on Contemporary Society, Faculty of Integrated Arts and Social Sciences, Japan \\ Women's University, Kawasaki, Japan; Honorary Associate, School of International Studies \\ and Education, Faculty of Arts and Social Sciences, University of Technology Sydney, Sydney, \\ Australia. Alexander.Brownduts.edu.au
}

Dol: http://dx.doi.org/10.5130/pjmis.v17i1-2.7094

Article History: Received 13/03/2020; Revised 02/06/2020; Accepted 08/06/2020;

Published 28/01/2021

\begin{abstract}
This paper argues for the importance of transnational memories in framing Australian anti-nuclear activism after the Fukushima disaster. Japan looms large in the transnational nuclear imaginary. Commemorating Hiroshima as the site of the first wartime use of nuclear weapons has been a long-standing practice in the Australian anti-nuclear movement and the day has been linked to a variety of issues including weapons and uranium mining. As Australia began exporting uranium to Japan in the 1970s, AustraliaJapan relations took on a new meaning for the Indigenous Traditional Owners from whose land uranium was extracted. After Fukushima, these complex transnational memories formed the basis for an orientation towards Japan by Indigenous land rights activists and for the anti-nuclear movement as a whole. This paper argues that despite tenuous organizational links between the two countries, transnational memories drove Australian anti-nuclear activists to seek connections with Japan after the Fukushima disaster. The mobilisation of these collective memories helps us to understand how transnational social movements evolve and how they construct globalisation from below in the Asia-Pacific region.
\end{abstract}


U T S

e PRES S

\section{Keywords}

Memory; Nuclear; History; Culture; Protest

\section{Introduction}

In March 2011, dramatic images of a hydrogen explosion at the Fukushima nuclear power plant flowed through global mediascapes (Appadurai 1996: 35-40) to Australia, where they appeared again and again on television screens, online media sites and in newspaper reports in the weeks and months following the disaster. One of the first public figures in Australia to respond to the disaster was Yvonne Margarula, Senior Traditional Owner of the Mirarr people, whose Country is located in the heart of the World Heritage listed Kakadu National Park in Australia's Northern Territory that includes the Ranger Uranium Mine. She wrote to the then United Nations Secretary-General Ban Ki Moon to express her concern that 'given the long history between Japanese nuclear companies and Australian uranium miners, it is likely that the radiation problems at Fukushima are, at least in part, fuelled by uranium derived from our traditional lands' (Gundjeihmi Aboriginal Corporation 2011).

Margarula remembered the transnational dimension of the Mirarr people's struggle against uranium mining in her letter, noting that the decision to mine uranium on her traditional land was the result of a 1974 agreement between Australian Prime Minister Gough Whitlam and Japanese Prime Minister Tanaka Kakuei. After Fukushima, she felt a direct connection with the people whose lives had been affected by the nuclear accident in northeast Japan and a responsibility for the poison that was taken from her Country. For Margarula, this responsibility was extinguished neither by the distance the uranium ore had travelled nor the fact that the decision to mine was made elsewhere. As sociologist Ulrich Beck (2000: 11) observes, today 'nothing which happens on our planet is only a limited local event; all inventions, victories and catastrophes affect the whole world.'The development of the nuclear energy industry in the 1950s and 1960s is an example of this. Australia's discovery of uranium ore and Japan's need for imported yellowcake was imbricated in the development of a global nuclear fuel cycle and in the transnationally connected struggles against uranium mining, nuclear power and nuclear waste disposal. As anti-nuclear activists in Australia responded to the Fukushima disaster, they drew on the legacy of anti-nuclear activism in both countries, including histories of joint action and solidarity, to argue that Australia should abandon its involvement in the global industry.

In this paper I consider the way transnational memories of nuclear harms and anti-nuclear struggle informed Australian nuclear activism after Fukushima. I argue that activists articulated their domestic activities within a transnational frame by remembering and commemorating histories of nuclear harm. The transnational implications of the Great East Japan Earthquake of March 2011 and the tsunami and nuclear disasters which it triggered have been the subject of a number of studies (Hindmarsh and Priestley 2015; Tsunekawa 2018). Nevertheless, as Jones, Loh and Satō (2013: 602-603) observe, there remains a tendency to restrict narratives about the Fukushima disaster to the national scale, depicting it as a failure of Japan's corporate and regulatory culture. They suggest that 'directing our attention to global, national, and local scales reveals alternative, intersecting narratives about what nuclear power meant, what interests it served, and who benefited' (619). Given the way nuclear fallout diffuses so readily through the atmosphere and the oceans, it seems self-evident that we should pay attention to the transnational when studying nuclear things. Moreover, viewing the disaster through a transnational frame provides an opportunity for contributing to the debate in area studies about the need to move beyond methodological nationalism. Recent historiography on Japan increasingly takes a transnational approach (Iacobelli Leary \& Takahashi 2016; Avenell 2017). Tessa Morris-Suzuki has called for an 'anti-area studies,' proposing an approach that 'uses knowledge of a variety of places and a variety of disciplinary approaches in order to elucidate problems which cross boundaries' (2000: 22). She rejects the methodological nationalism implicit in Japanese Studies 
U T S

e P RES S

that focus on the bounded territory of 'Japan' and posits an approach that allows 'people and places in Australia [to] become part of the problem to be understood and "read" - in an interconnected series of points upon the earth, not only reflecting but becoming objects of reflection' (22). Chapman and Hayes (2020) exemplify such an approach in their recent collection of essays on Japan in Australia, underlining how the modern histories of these two Pacific nation states have been mutually constituted through transnational cultural flows. In this paper I apply a similar methodological approach by investigating the presence of Japan in the memories of Australian anti-nuclear activists, showing how memory practices facilitate activism beyond borders.

When the Great East Japan earthquake struck in 2011, I had already planned to travel to Japan to conduct research on social movements in Tokyo. The earthquake and nuclear disaster threatened to derail my plans as Australian Government travel warnings and anxious cautions from friends and family made me question my plans to travel to a potentially radioactively contaminated city. Ultimately, however, I decided to take the journey and arrived in Japan in late September for an eighteen-month research trip. Having already been involved in anti-nuclear movements in Australia before Fukushima, I re-engaged with the resurgent anti-nuclear movement after the disaster. This included grassroots organising in my hometown of Wollongong in Australia between March and September 2011 and extensive engagement with the movement in Japan during my eighteen months living there. These experiences drew my attention to the intersections between anti-nuclear movements in the two countries and caused me to reflect on the contours of the transnational civil society that emerges from this intersection. This paper thus draws in part on my own personal experiences of the transnational movement and connections that were formed in the wake of the disaster, a methodological approach Routledge (2013) describes as 'activist ethnography.'

I begin by reviewing some of the literature on globalisation, transnational social movements and transnational memory, noting the gap in the literature regarding Australia-Japan as a transnational space for grassroots political action. I then provide some background on anti-nuclear struggles in Australia before Fukushima and the way these struggles engaged with Japan's history as a target of nuclear attack and as a growing nuclear energy producer. I then explore two examples of transnational anti-nuclear activism between the two countries after Fukushima: transnational activism by Australian Indigenous people and the staging of anti-nuclear demonstrations on Hiroshima Day in the regional Australian city of Wollongong. In each case I show that practices of remembering previous struggles served to connect the movement in Australia transnationally with that in Japan.

\section{Transnational Activism and Transnational Memory}

For Beck (2000: 12), globalization is an ongoing process which 'create[s] transnational social links and spaces, revalues local cultures and promotes third cultures.' He distinguishes contemporary processes of globalisation, which are characterised by the 'scale, density and stability of regional-global relationship networks and their self-definition through the mass media, as well as of social spaces and of image-flows at a cultural, political, economic and military level' (12) from a long-established globality, which was created in earlier waves such as colonialism. Studies of social movements increasingly focus on the transnational. The alter-globalisation movement in the late 1990s and early 2000s, which was epitomised by the mass protests against the World Trade Organisation in Seattle in 1999, inspired a range of studies that sought to understand these movements and the ways in which activists, ideas and practices circulate beyond the borders of the nation state (Della Porta 2007; Starr 2000). The Seattle protests were made possible by the networking of activists, NGOs and other civil society groups under the umbrella of People's Global Action, which enabled them to develop a coordinated response to corporate globalisation (Graeber 2002: 63). In this dynamic form of grassroots globalisation, activists develop transnational networks in response to the challenges of corporate globalisation and use them to articulate a global vision based on solidarity 
U T S

e PRE S S

rather than competition (Reitan 2012). The need to pay attention to the transnational can also be seen in recent historical studies of labour and other social movements (Piccini 2016; Van der Linden 2017). When compared with the substantial literature that has emerged on the alter-globalisation movement and its transnational practices, however, the transnationalism of social movements in East Asia remains underexplored.

One approach to thinking through transnational social movements is to examine the transnational circulation of memories of struggle. The bombing of Hiroshima and its memorialisation were central to the development of global memory culture (Zwigenberg 2014; Yoneyama 1999). The global turn in memory studies challenges the privileging of the nation. Mackie and Crozier-De Rosa (2019), for example, explore memory practices in transnational feminism, a social movement that has always carried with it either an explicit or implicit transnational frame. As Mackie and Crozier-De Rosa (2019: 3) point out, the notion of collective memory has been criticised for its homogenising tendencies and stress the need to emphasise the mutability and contested nature of memory-making. Notions of collective memory have tended to privilege the nation as a site of remembering, particularly given the importance of place in understanding how memory is produced beyond the individual level. Global memory culture provides a transnational frame through which to look at spatially contextualised historical events, as can be seen in the way memories of the Holocaust in Europe have produced a set of ethical and political imperatives that go beyond the nation state. Yet, as Sundholm (2011: 2) points out, the construction of a global memory culture does not obviate the need for thinking about memory practices in local contexts. James Clifford (2013: 41) observes that the global-local dichotomy is a false one, in which "both ideas equally abstract and ideological'. He calls instead for a 'realist' approach, 'which works with "big-enough," more-than-local narratives.'

Australia-Japan as a space of movement and memory remains unexplored. One of the few exceptions is Renwick and Walton's (1992: 112) study of peace movement relations between Australia and Japan, which includes anti-nuclear movements. They found that a 'multi-tiered and multi-dimensional' relationship was maintained through organisational and individual contacts through multilateral, bilateral, formal and informal channels, though they were sometimes ad hoc. However, they conclude that 'the fragmentary nature of the respective movements complicates their interaction' and 'restricted organisational contacts' (120-121). They found that that connections between movements in the two countries depend 'largely upon individuals with some form of personal interest or commitment to Japan-related peace issues' and experiences of living and working in Japan, friendship networks and other relationships (114).

Renwick and Walton do not use the language of memory to interrogate Australia-Japan social movements. Instead, they draw on an undefined concept of 'organisational memory' in order to posit that a lack of organisational continuity between movements in the two countries leads to a deficit of 'organisational memory' (121) at the transnational scale. In management studies, the notion of 'organisational memory' refers to 'stored information from an organization's history that can be brought to bear on present decisions' (Walsh and Ungson 1991: 61). They apply this approach to the problem of organisational continuity and its strategic implications for cross-border peace movement relations. This perspective is common to both instrumentalist sociologies of social movements and to many social movement actors, who often see movement culture as a tool for achieving movement goals rather than as an end in itself (Eyerman \& Jamison 1998: 168). Indeed, organisational theory has been influential in structuralist social movement theories (Davis et al. 2005).

My approach draws on a different understanding of social movement culture as representing 'an alternative vision and way of life to that of the dominant society' (Eyerman \& Jamison 1998: 170). I have also observed the lack of clear organisational continuities between movements identified by Renwick and Walton in Australia and Japan in my own activist ethnography of Australia-Japan social movements. My focus in this paper is therefore to consider how struggles over issues such as uranium mining and nuclear power continue to produce lively cross-border interchanges despite a lack of organisational continuity. 
U T S

e PRE S S
My hypothesis is that while the 'organisational memory' of an Australia-Japan anti-nuclear movement embedded in formal structures is weak, this weakness is compensated by the culture of transnational struggle that has been created and communicated through collective memories.

A number of recent studies have examined memory within social movements. Anna Wiemann (2019), for example, examines how movement intellectuals use history and memory to frame their accounts of the anti-nuclear movement in Tokyo after the Fukushima disaster. Wiemann draws on Ann Rigney's (2018) framework for understanding the relationship between memory and activism. Rigney identifies three instances of what she calls 'the memory-activism nexus': memory activism, memories of activism, and memory in activism. In memory activism, activists engage directly in the struggle to produce cultural memories. Memories of activism concerns the ways in which we remember past struggles. Finally memory in activism refers to the ways in which cultural memories of past struggles inform new movements. Bringing these three instances together, she notes that 'remembering the past, shaping the future remembrance of the present, and struggles for a better future feed into each other' (372). In this paper, I am particularly concerned with the third of these categories, the role of memory in activism, and the way it has served as a link to connect pre- and post-Fukushima nuclear activism in Australia with Japan.

Discussing the terminological profusion that plagues memory studies, Kansteiner highlights Assmann's (1995) distinction between cultural memory as the forms of objectified culture through which societies develop and transmit an image of themselves and communicative memory, the 'everyday communications about the meaning of the past characterized by instability, disorganization, and non-specialization' and which tends to occupy a time-span of less than one hundred years (Kansteiner 2002: 182). If applying this distinction to memories of the nuclear age, we are entering the terrain of communicative memory that is in the process of becoming cultural memory. Kansteiner explains how the more ephemeral processes of communicative memory leads to the creation of more widely shared and institutionally embedded cultural memories: 'Collective memories originate from shared communications about the meaning of the past that are anchored in the life-worlds of individuals who partake in the communal life of the respective collective' (188). For activist movements, communicating memories of nuclear harms helps to develop a collective memory about the nuclear past which they hope to embody in the construction of a nuclear-free future.

The power of collective memories lies in how they are articulated with individual memories. The affective dimension of memory seals this connection. Eyerman and Jamison's work on music and memory in social movements provides a useful point of reference here. They use a 'structure of feeling' model for understanding collective memory, arguing that music 'creates a mood ... and in this way can communicate a feeling of common purpose, even amongst actors who have no previous historical connections to one another' (1998: 161-162). They stress the ways in which music 'can be recorded and reproduced ... to such an extent that it can be recalled or remembered at other times and places.' Music, however, is not the only cultural form that is capable of structuring feelings and communicating emotion across time and space. Below I examine examples of Indigenous testimony and an activist protest ritual where the affective power of memories derives from the individual and family experiences of the witnesses and from participation in the protest ritual. My analysis explores how memories of nuclear harm and anti-nuclear protest are produced and reproduced in a transnational space that incorporates Australia and Japan. But first it is necessary to briefly outline some of the historical legacies of the nuclear age in the Australia-Japan context.

\section{Radioactive Legacies}

After the Second World War, the United States sought to promote its allies' development of civilian nuclear power technologies in a plan outlined by President Dwight D. Eisenhower in a speech at the General Assembly of the United Nations in 1953. Japan was eager to take advantage of the technology transfers available under the new policy, dubbed 'Atoms for Peace.' Conservative politician Nakasone Yasuhiro 
U T S

e P RES S

shepherded Japan's first bill appropriating money for a nuclear power programme in March 1953 and chaired a bipartisan committee in the National Diet that saw the basic legal framework for nuclear power established by the end of 1955 (Yoshioka 2011: 69-72). However, the early development of Japan's nuclear programme was plagued by technical problems. The first commercial nuclear reactor, using imported British technology, commenced operation in 1965. By 1970, Japan had four functioning reactors. Following the oil shock crises of the early 1970s, Japan's determination to pursue the nuclear option increased as part of a strategic orientation away from dependence on imported oil. By 1980 Japan had 22 reactors, making up 11 per cent of world nuclear generating capacity (Nuclear Energy Agency and the International Atomic Energy Agency 2006: 22).

While the development of Japan's nuclear power industry was premised on the quest for energy autarky, Japan lacked sufficient domestic reserves of uranium leading utilities to import uranium to guarantee supply (Nuclear Energy Agency and the International Atomic Energy Agency 2006). The establishment of nuclear power infrastructure in Japan and other countries in the 1960s stimulated a boom in exploration activities in Australia. Significant uranium reserves were discovered between 1969 and 1975, including a number of large deposits in the Alligator Rivers Region of the Northern Territory such as Ranger and Jabiluka (Falk, Green \& Mudd 2006). In 1966 Japan began to look overseas for supplies, including to Australia (Nuclear Energy Agency and the International Atomic Energy Agency 2006: 286). On returning to Japan from a research trip to Australia in February, Kamiyama Teiji of the Power Reactor and Nuclear Fuel Development Corporation, gave a press conference where he urged that 'as a nation we too need to look to Australia,' and warned that 'if we do not act quickly to develop uranium mining in Canada, Australia and other foreign countries we will be too late' (Asahi Shimbun 1967: 7). In February 1972, Australia and Japan signed an Agreement for Cooperation in the Peaceful Uses of Atomic Energy. The agreement, which replaced an earlier 1962 agreement, was intended to facilitate the transfer of nuclear materials, including uranium ore (Asahi Shimbun 1972: 2). This set the stage for the establishment of the uranium trade from Australia to Japan. However, as the controversial global nuclear industry expanded across the world, so did opposition to it.

When Australian Prime Minister Gough Whitlam promised his Japanese counterpart Tanaka Kakuei that Australia would supply Japan with uranium, his decision triggered the birth of an anti-uranium movement in Australia (O’Brien 2003; Burgmann 2003). Activists in Australia held protest actions such as the Ride Against Uranium in 1975, which took the anti-uranium message to Canberra in a multiday bicycle protest originating in Melbourne, Sydney and Adelaide. In 1976 the Whitlam government commissioned the Ranger Uranium Environmental Inquiry, to examine the uranium mining proposal, making the uranium debate a major public focus. As the movement opposing uranium mining grew, activists established links with activists in Japan (Sibatani 1977). In the early days of the nuclear energy industry in Japan, opposition was largely limited to local struggles against particular reactor siting plans. However, over the course of the 1970s, these groups began to co-ordinate their opposition and a number of prominent scientists joined the cause. This led to the development of national and international movement links. Japanese environmentalists and anti-nuclear campaigners became aware that Japan's high economic growth relied on resource extraction and the export of polluting industries to poorer countries, often former Japanese colonies, thus contributing to a broader transnational understanding of their struggle (Avenell $\underline{2016}, \underline{2017})$.

The controversy over uranium mining at Ranger was captured at the time in the documentary film Dirt Cheap (1980). The film includes a hidden microphone recording of Fraser government Minister for Aboriginal Affairs Peter Viner telling Traditional Owners that they have no choice but to assent to uranium mining on their Country so that Australia could supply the Japanese uranium market. Following the meeting, traditional owners signed an agreement under pressure giving consent to the construction of the Ranger mine (Cawte 1992: 158-61). When the mining lease for Ranger was granted in 1979, the 
U T S

e P RES S

government quickly sold off its interest and a new company, Energy Resources Australia, was formed in which a Japanese consortium held a 10 per cent stake. Doug Anthony, minister for trade and industry in the Fraser government, justified the sale on the grounds that 'only because overseas interests had a direct equity interest in the venture that they were prepared to enter into long-term contracts' (Cawte 1992: 162). This is indeed what took place in 1978, when Kansai Electric Power, Shikoku Electric Power and Kyūshū Electric Power signed long-term supply contracts to purchase uranium from 1982 to 1996 (Tsūshōsangyōshō shigen enerugii chō kōeki jigyōbu genshiryoku hatsuden ka 1987: 269-70). As Edgington (1984: 1024) explains, this was a typical pattern of Japanese investment in the Australian minerals sector in the early 1980s, with firms holding small equity stakes in mines and signing long-term contracts to purchase the output.

Much of the concern about uranium mining in Australia in the 1970s and 1980s centred on nuclear weapons proliferation. The bombings of Hiroshima and Nagasaki provided a clear example to many why uranium should be left in the ground. Hiroshima Day rallies had become an annual protest ritual for antinuclear campaigners as early as the 1960s, before the uranium mining issue had penetrated the political agenda in Australia. In 1961, 5,000 marched in Sydney and 3,000 in Melbourne. By 1962 Hiroshima Day was becoming 'with May Day another fixture in the calendar of the left in Australia' (McCausland 1999: 84-85). Globally, the movement registered a major success in 1963 with the conclusion of a partial test ban treaty. As Hiroshima Day became an established ritual of commemorative protest in the Australian calendar, it served as a focus for further peace and anti-nuclear protest waves. Opposition to the Vietnam War became the major focus for Hiroshima Day in 1965 and the day remained a key protest event for the anti-Vietnam War movement. When uranium mining concerns surfaced in the 1970s, Hiroshima Day once again became a symbolic day for taking action. As Australia withdrew from Vietnam following the election of the Whitlam government, much of the anti-war movement turned its attention to the impending plans to export Australian uranium (Adamson 1999). Even after the commencement of mining at Ranger, opposition to nuclear weapons and uranium mining fuelled major social movements throughout the 1980s, such as the campaign against the Roxby Downs uranium mine in South Australia and for a nuclear free Pacific.

A second major wave of anti-uranium mining protests took place in Australia in the 1990s, when the newly elected Howard Government cleared the way for the owners of the Jabiluka uranium deposit near Ranger in the Northern Territory to begin mining as part of a much-talked-about nuclear renaissance. The Mirarr people, Traditional Owners of the Jabiluka mine site, opposed mining and led a national and international campaign that helped to prevent mining of the Jabiluka deposit. Senior Traditional Owner Yvonne Margarula was at the forefront of this struggle (Branagan 2014: 4-11). Appeals to international law were an important part of Mirarr strategy in their struggle against the expansion of uranium mining on their Country in the 1990s, when their Gundjeihmi Aboriginal Corporation sought to have the Kakadu National Park listed as a World Heritage site in danger during their battle against the proposed uranium mine (Hintjens 2000: 379). The Jabiluka campaign made links with activists around the world, including in Japan, and Japanese activists highlighted the connection between uranium mining on Indigenous lands and the nuclear energy industry in Japan (Itō 2004). Jabiluka Action Groups took action on Hiroshima Day in 2000, showing how the day continues to serve as a mnemonic link with the history of nuclear devastation in Hiroshima and at the Maralinga nuclear test site in South Australia, which like uranium mining has disproportionately affected Indigenous peoples (Hintjens 2000: 379).

\section{Indigenous Memories}

I opened this paper with reference to Yvonne Margarula's letter to the United Nations, where she drew attention to the way the transnational history of nuclear power in Japan and Australia implicated her traditional lands in the Fukushima disaster. Before Fukushima, Australia was a major source of uranium 
U T S

e P RES S for the Japanese nuclear energy industry, supplying approximately one third of its needs (Nakamura 2011; World Nuclear Association 2019). Margarula's suspicions about the source of the uranium fuel that was melting down inside the stricken reactor vessels of the Fukushima nuclear power plant, were later confirmed by Dr Robert Floyd, Director-General of the Australian Safeguards and Non-proliferation Office in the Department of Foreign Affairs and Trade. On 31 October 2011, Floyd told a Joint Standing Committee of the Australian Parliament that 'Australian obligated nuclear material was at the Fukushima Daiichi site and in each of the reactors-maybe five out of six, or it could have been all of them; almost all of them' (Commonwealth of Australia 2011). His office was able to confirm the presence of Australian uranium at the Fukushima Daiichi nuclear power plant as part of its role in ensuring Australia meets its international obligations under a variety of safeguards agreements. Australia's uranium export policy obligations under these agreements involve 'precisely accounting for amounts of Australian-Obligated Nuclear Material (AONM) as it moves through the nuclear fuel cycle' (Department of Foreign Affairs and Trade n.d.).

The Mirarr people's memories of their struggles with uranium mining and those of other Indigenous groups who had collective memories of nuclear harms were central to the actions they took in solidarity with the people of Fukushima after the March 2011 disaster. Prior to the disaster, Gundjeihmi Aboriginal Corporation had begun working with Environment Centre NT, a local environmental NGO, to reissue the 1980 film Dirt Cheap, which depicts the struggle over uranium mining on Mirarr Country in the 1970s. The reissued film Dirt Cheap 30 Years On: The Story of Uranium Mining at Kakadu (2011), incorporates sections of the original film alongside messages about Fukushima and the ongoing struggle against uranium mining in Kakadu. Historical footage of Toby Gangale and other Indigenous leaders and environmental activists fighting the plans to mine at Ranger is prefaced with a commentary aimed at a post-Fukushima audience. The documentary begins with a montage of Australian television news footage reporting on the hydrogen explosion and subsequent meltdown at Fukushima. This ensures that viewers make a direct connection between Ranger's history and the Fukushima disaster by inviting them to remember these histories, highlighting 'the lessons and legacy of Fukushima [that] have a particular relevance to Australia today.' The documentary asks us to remember the original injustices which surrounded the signing of the Ranger mining agreement when we remember the Fukushima disaster.

When Margarula referred to the 'long history between Japanese nuclear companies and Australian uranium miners' in her letter to the UN, she evoked her own family's struggle documented in Dirt Cheap (Gundjeihmi Aboriginal Corporation 2011). In Dirt Cheap 30 Years On, Margarula explains how her father was dragged along to these meetings to negotiate on the Ranger mine, eventually signing the paperwork under pressure that assented to the mine. In Margarula's letter and her video testimony, she interprets the Fukushima nuclear disaster as a direct realisation of these fears. Her ability to conceptualise a local issue in a transnational frame exemplifies the transnational imaginary that informs Indigenous anti-nuclear activism in Australia and the role of history and memory in sustaining anti-nuclear struggle.

A shorter clip from the film containing Margarula speaking about her father's struggle against uranium mining in the park was also shared via YouTube (keb1974 2013). This clip highlighted the slogan 'Australian Uranium Fuelled Fukushima,' which bookends Margarula's testimony in stark, unadorned white letters against a black background. This slogan, which highlights the dependency of the Japanese nuclear industry on extractive industry, encapsulates the main argument made by Australian anti-nuclear activists when communicating with their counterparts in Japan. It was observed at anti-nuclear demonstrations across Australia (Workers Bush Telegraph 2012; Mackie 2015). The film clip has been shared widely on social media, despite the relatively small number of activists involved in the campaign. Furthermore, it continues to serve as a reference point for activists working between Australia and Japan, such as the Smile with Kids programme in Cairns. This small charity in Cairns partners with Earthwalker, a Not-for-Profit Organisation based in Fukushima prefecture. They organise short-term respite trips for children from Fukushima 
U T S

e PRE S S prefecture who experience elevated radiation levels in their environment to come to Cairns and play freely outside without fear of elevated radiation levels while engaging in a wide range of educational activities.

The Olympic Dam mine near Roxby Downs in South Australia is the largest uranium mine in the world. Like Ranger, it has a bitterly contested history and local Indigenous groups and individuals have long memories of the impact of the mine and of other nuclear harms on their Country and communities. In early 2012, South Australian Indigenous leader Peter Watts, an Arabunna man and Co-Chair of the Australian Nuclear Free Alliance, travelled to Japan to address the Global Conference for a Nuclear-Power Free World: a major event held at the Pacifico convention centre in Yokohama on 14-15 January 2012. The conference attracted 11,500 people over two days and included a hundred invited international guests from thirty countries (Global Conference for a Nuclear Power Free World 2012). Its stated purpose was to 'give birth to concrete support for the people of Fukushima, be a further step towards creating a future without nuclear power plants, and develop into ongoing global action' (Yoshioka 2012). Like Margarula, Watts spoke directly from his own and his people's collective memories of harms both historical and ongoing caused by nuclear weapons testing and uranium mining on Country. Watts' traditional lands include the site of BHP's Olympic Dam mine, which supplies uranium to customers in Japan. In speaking to the Japan Times, Watts made reference to ancestral memories of the harms associated with uranium, stating: 'Our ancestors knew of the uranium ... They called the places (of uranium deposit) "Poison Country" (Arita 2012).

Both Margarula and Watts' testimony about the impact of uranium mining on their lands carries a powerful affective charge because of the deeply personal impact of nuclear issues on themselves and their family members. The emotional power of the testimony comes through clearly in their acts of public witnessing on the transnational stage and in the sympathetic responses they generate. When the abovementioned middle school students from Fukushima watched the footage of Margarula describing her family's experiences, they recorded a range of emotional reactions on the public archive of their tour. All were struck by the responsibility Margarula felt for the Fukushima disaster and a number noted how it had changed their own perspective on what happened. One student wrote, 'She felt really sorry and apologised. When I heard it, I felt like we Japanese were also the perpetrators. I had mixed feelings.' Another wrote: 'These people are not to blame; in fact, it's the people who did not listen who are bad. So why are they feeling so sorry about it and grieving so much? If it were me, I would just say, 'I warned you but you didn't listen!'... The uranium people are very kind' (Smile with Kids 2019).

Watts' journey to Japan also led to emotional encounters with local victims of the Fukushima disaster. During a visit to a tent embassy protest established by anti-nuclear activists outside the Ministry of Economy, Trade and Industry building in Kasumigaseki, Watts shed tears with a visiting woman from Fukushima as they exchanged their experiences of nuclear harms (마으 2012). These affective encounters create powerful memories, outlasting the specific circumstances in which they occurred and potentially opening up an affective space of transnational memory that encompasses the Australia-Japan space.

\section{Remembering Hiroshima to Remember Fukushima}

As Vera Mackie (2015) explains, alongside uranium mining Indigenous anti-nuclear consciousness in Australia is also tied to the memory of Hiroshima and Nagasaki and to the experience of British nuclear testing at Maralinga in South Australia. Indigenous activism highlights the importance of memories Hiroshima in providing a framework for understanding later nuclear events such as Fukushima. For Indigenous opponents of uranium mining, the threat of imbrication in a Hiroshima-like situation was one of the reasons they articulated for opposing uranium mining. When Toby Gangale, Yvonne Margarula's father, explains his opposition to uranium mining in Dirt Cheap with reference to the use of nuclear weapons at Hiroshima: 
I didn't like the mine you see ... Big danger mine. Very dangerous. What if they make an atom bomb or something? Very dangerous. Same thing they did in Japan. Flat. All the big houses, all the big buildings. Very danger. That's why we're worried.

Given the way Hiroshima Day connects Australia's history of anti-nuclear protest with histories of nuclear harms in Japan, a number of commemorative events organised that year had a focus on Fukushima. These took place along the eastern seaboard, in the state capitals of Brisbane, Sydney, Melbourne and Hobart as well as in regional centres like Wollongong and Broken Hill (Ross 2011). Sydney Hiroshima Day Committee organiser Denis Doherty noted that while Hiroshima Day in Sydney has 'been largely ignored by Japanese expats' since its inception in 1978, 'this year is different. Japanese people are calling up and wanting to help organise the rally, join the rally. Fukushima is bringing them out' (Ross 2011). Vera Mackie (2015), too, describes how the Melbourne-based Japanese For Peace group, which was organised by the expatriate Japanese community in Melbourne in 2005, became actively involved in anti-nuclear protest after Fukushima. The response to the Fukushima disaster drew on existing conceptions of a transnational civil society and the global memory culture that had strong local roots in some Australian communities.

As discussed, Hiroshima Day became an important commemorative protest ritual linking anti-nuclear weapons, anti-war and anti-uranium campaigns in Australia from the 1960s right through to the Jabiluka campaign of the late 1990s. Furthermore, the importance of Hiroshima Day was not limited to major capital cities but has become entrenched in the labour and social history of some regional centres, such as my hometown of Wollongong on the south coast of New South Wales (Brown and Southall 2019). An advertisement for the 1986 Hiroshima Day rally appearing in a University of Wollongong student newspaper, for example, articulates the connection activists made between nuclear weapons, nuclear power, peace and military bases in slogans such as 'No Foreign Bases,' $N o$ Nuclear Ship Visits,' Radiation Knows No Borders,' and 'Stop Uranium Mining' ('Hiroshima Never Again' 1986). The rally was part of local efforts to embrace the United Nations' designation of 1986 as the International Year of Peace (IYP). In that year, 1,000 people turned out for the Hiroshima Day march ('1000 in Peaceful March' 1986). The organising committee also installed a brass plaque commemorating the International Year of Peace in the city's central mall where the abovementioned rallies took place.

I had been attending the annual Hiroshima Day commemorations in Wollongong for a number of years prior to the Fukushima disaster. The usual format for the event involves a small group of dedicated peace activists, primarily veterans from earlier waves of peace movement activism, gathering early in the morning to sing songs of peace, make short speeches and observe a minute's silence at 8:15am, the time the atomic bomb was dropped on the city of Hiroshima. When issues arise that demand a response from peace and anti-nuclear activists, this annual commemoration and protest serves as a focal point for rallying anti-nuclear sentiment and regular participants in the commemorative event form part of a loose network of peace and anti-nuclear activists. After the Fukushima disaster, I joined with a group of local people to form a new anti-nuclear activist group in response both to the Fukushima disaster in Japan and to plans by the Australian government to build a medium-term radioactive waste dump on Aboriginal land at Muckaty Station in the Northern Territory (Brown 2011). The group quickly forged links with existing local networks of peace, trade union and student activism. We resolved to hold a rally on Hiroshima Day to protest Fukushima and the nuclear energy industry. Mindful of the existing annual commemoration, we timed our rally to take place later in the day at the same location in central Wollongong around the International Year of Peace plaque. Around 30 people turned out for this commemorative event, which has been organised annually by the local Hiroshima Day Committee since 1979. Later in the morning approximately one hundred people attended our 'Rally for a Nuclear Free Future.'

Speakers at the rally denounced both nuclear power and nuclear weapons. After a welcome to Country from a local Indigenous elder, a number of speakers addressed the crowd. One feminist activist from Japan 
U T S

e PRES S

spoke at the rally, reading aloud from the poem 'When we say "Hiroshima" (in Dougherty 2011) by the hibakusha poet Kurihara Sadako. In this poem, Kurihara invokes the memory of Japan's own wartime atrocities into the narrative of Hiroshima. She reminds her readers that the victims of Japan's own war crimes should be remembered alongside those of Hiroshima and Nagasaki (Styczek 2010: 113). ${ }^{1}$ The poet reinserts non-Japanese victims of wartime atrocities into the collective memory of Hiroshima. Reading the poem at our rally, the activist reminded us of the Japanese nuclear industry's dependence on uranium mining on indigenous lands in countries like Australia and connected their memory struggles with the ongoing and contested memorialisation of Hiroshima.

Ron Eyerman and Andrew Jamison's (1998) work on music and memory in social movements discusses the role of songs as 'channels of communication' for activists within particular movements, between movements and across generations. The same is true of poems such as Kurihara's. The poem, like much of Kurihara's work, is deeply emotionally affecting. Performed in the context of a Hiroshima Day rally in Wollongong after Fukushima, its emotional charge helped create an affective link between the reader, the attendees at the rally and a collective memory that is shared by anti-nuclear protest groups at the transnational scale. When I was asked to speak at a subsequent Hiroshima Day rally in Wollongong in 2018, I too chose to read one of Kurihara's poems. I had learned about the poet and her work at the earlier event in 2011. I struggled to read 'Let us be midwives!' (in Dougherty 2011), choking back tears as I engaged in the affective journey of the poem, which describes a midwife helping to deliver a baby while hiding in a basement room in the aftermath of the bomb before succumbing to her own injuries. A tiny group of people gathering to commemorate Hiroshima and the history of nuclear harms might easily be dismissed. However, when viewed as an occasion to forge an affective transnational memory of nuclear harm, we can see how these memory practices can maintain the community of memory over time, even in the absence of strong ongoing organisational structures.

\section{Conclusion}

Renwick and Dalton (1992: 121) worried about the lack of 'organisational memory' in the Australia-Japan peace movement in their survey. In this paper I have discussed the way memory practices in Indigenous activism, filmmaking and demonstrations, help sustain a transnational collective memory of activism that encompasses Australia and Japan. This memory culture is sustained by organisations such as Gundjeihmi Aboriginal Corporation, Wollongong's Hiroshima Day Committee and TWANG, as they enact practices of remembering. Existing organisations in Wollongong and Sydney, which had been holding Hiroshima Day commemorations for a number of decades, provided a ready-made organisational and symbolic container for anti-nuclear power messages after Fukushima. While organisational memories of activism linking Australia and Japan remain tenuous in institutional terms, practices of memorialisation insert transnational memories back into domestic anti-nuclear activism in Australia, providing an ongoing framework for connecting with anti-nuclear struggles in Japan.

The Fukushima disaster provided a powerful incentive for anti-uranium activists in Australia to reforge connections with Japan in the hope of reducing demand for uranium and thereby curtailing uranium mining activities in Australia. Some anti-nuclear activists in Japan, too, looked outward and sought to address the ways in which the disaster in Japan was connected to the global nuclear fuel cycle. The slogan 'Australian Uranium Fuelled Fukushima' encapsulated this attempt to highlight the connection between uranium mining and the disaster in Japan. Memory practices enable the performance of otherwise ephemeral connections to maintain the consciousness of global interconnectivity among activists. For the Indigenous activists discussed in this paper, the memory of Hiroshima and Nagasaki informs their opposition to

1 Kurihara's poetry has undergone its own transnational circulation in English translation as well as in a number of other languages. In addition to Styczek (2010), see also Hayakawa (2012). 
U T S

e PRES S

uranium mining on Country. Similarly, for anti-nuclear activists in Wollongong, the memory of Hiroshima and the annual rituals of commemoration and protest that kept those memories alive provided a theoretical and organisational infrastructure that sprang into life after the Fukushima disaster.

Beck (2000: 31) observes that one of the defining features of globalising 'lies in the empirically ascertainable scale, density and stability of regional-global relationship networks and their self-definition through the mass media, as well as of social spaces and of image-flows.' Drawing on such reflexive understandings of their global situatedness enables local activists to situate themselves in global spaces through acts of commemoration such as the Hiroshima Day events and by viewing and sharing their activities in traditional media and via the internet. Indigenous activists and the Environment Centre NT, for example, produced Dirt Cheap 30 Years On and made short clips for circulation on YouTube in order to intervene in global mediascapes and share their message about the connection between Australian uranium mines and Japanese nuclear reactors. Despite the challenges posed by the physical and cultural distance between Australia and Japan, the mediatisation of transnational memories helps produce and maintain a transnational imaginary, even where one-to-one contacts between individuals in different countries remain limited. Nevertheless, as Kansteiner (2002: 195) notes, we are living in an era in which 'the consumption of history becomes more and more discontinuous and fragmented in time and space.' This leads to a proliferation of memory communities who struggle to shape broader collective memories. For the anti-nuclear movement, the terrain of struggle is to expand the community of memory, generalising the memories of nuclear harm as cultural memory and thereby making uranium mining and nuclear power generation culturally and politically unacceptable. The declining fortunes of the nuclear industry in the post-Fukushima era suggests that memories of the disaster have had a powerful impact. Attitudes towards nuclear power in Australia have become much more negative since the disaster (Bird et al. 2014). For social movements, the impetus remains to continue communicating memories of nuclear harm so that they take on an enduring form as cultural memories. Global memory culture in the nuclear age is a culture in the making. The way we remember the past seems set to remain central to the work of nuclear activists into the future.

\section{Acknowledgements}

The research and writing for this paper were begun at University of Technology Sydney and completed at Japan Women's University, while I was a Japan Society for the Promotion of Science International Research Fellow. Thanks to Professor Shibuya Nozomu for providing such a supportive research environment. I would also like to thank the reviewers and journal editors for their thoughtful comments.

\section{References}

‘1000 in Peaceful March,' 1986, The Advertiser, 13 August: 12.

Dirt Cheap, 1980, motion picture, Australian Film Institute.

Dirt Cheap 30 Years On: The Story of Uranium Mining at Kakadu, 2011, Gundjeihmi Aboriginal Corporation in association with The Environment Centre NT. Online, available: https://vimeo.com/73373709 (Accessed 30 August 2018).

'Hiroshima Never Again,' 1986, Tertangala, vol. 12, no. 6: 17.

Adamson, G. 1999, Stop Uranium Mining! Australia's Decade of Protest 1975-85, Resistance Books, Chippendale.

Appadurai, A. 1996, Modernity at Large: Cultural Dimensions of Globalization. University of Minnesota Press, Minneapolis. 
U T S

e PRES S
Arita, E. 2012, 'From Aboriginal Land to Japan's Nuclear Reactors,' The Japan Times, 19 February. Online, available: http://www.japantimes.co.jp/life/2012/02/19/general/from-aboriginal-land-to-japans-nuclear-reactors/ [Accessed 17 August 2018].

Asahi Shimbun 1967, ‘Gō no uran kaihatsu o isoge,'19 February: 7.

Asahi Shimbun 1972, ‘Genshiryoku kyōtei o musubu,' 18 February: 2.

Assmann, J. 1995, 'Collective Memory and Cultural Identity,' New German Critique, vol. 65: 125-133. https://doi. org $/ 10.2307 / 488538$

Avenell, S. 2016, 'Antinuclear Radicals: Scientific Experts and Antinuclear Activism in Japan,' Science, Technology and Society, vol. 21, no. 1: 88-109. https://doi.org/10.1177/0971721815622742

Avenell, S. 2017, Transnational Japan in the Global Environmental Movement, University of Hawai 'i Press, Honolulu. https://doi.org/10.26530/OAPEN 627002

Beck, U. 2000, What is Globalization? Patrick Camiller, trans., Polity Press, Cambridge.

Bird, D. K., Haynes, K., van den Honert, R., McAneney, J. \& Poortinga, W. 2014, 'Nuclear Power Australia: A Comparative Analysis of Public Opinion Regarding Climate Change and the Fukushima Disaster,' Energy Policy, vol. 65: 644-53. https://doi.org/10.1016/j.enpol.2013.09.047

Branagan, M. 2014, 'The Australian Movement Against Uranium Mining: Its Rationale and Evolution,' International Journal of Rural Law and Policy, Special edn 1: 1-12. https://doi.org/10.5130/ijrlp.i1.2014.3852

Brown, A. 2011, 'Peace Activists Mark Hiroshima Day,' Green Left Weekly, 11 August. Online, available: https://www. greenleft.org.au/content/peace-activists-mark-hiroshima-day [Accessed 30 August 2018].

Brown, A. 2012, 'Australian Activists Address Global Anti-Nuclear Conference,' 3 February. Online, available: https:// www.greenleft.org.au/content/japan-australian-activists-address-global-anti-nuclear-conference [Accessed 30 August 2018].

Brown, A. \& Southall, N. 2019, 'An Interview with Nick Southall (3 Parts),' The Word from Struggle Street. Online, available: https://thewordfromstrugglestreet.wordpress.com/2018/11/12/the-party-was-like- our-family-an-interviewwith-nick-southall-part-1/ [Accessed 1 June 2020].

Burgmann, V. 2003, Power, Profit and Protest: Australian Social Movements and Globalisation, Allen \& Unwin, Crows Nest.

Cawte, A. 1992, Atomic Australia, 1944-1990, New South Wales University Press, Kensington.

Chapman, D. \& Hayes, C. (eds) 2020, Japan in Australia: Culture, Context and Connections, Routledge, London. https:// doi.org/10.4324/9780429196485

Clifford, J. 2013, Returns: Becoming Indigenous in the Twenty-First Century, Harvard University Press, Cambridge. https://doi.org/10.4159/9780674726222

Commonwealth of Australia Joint Standing Committee on Treaties, 2011. 'Treaties Tabled 23 August, 13 and 20 September 2011,' Official Committee Hansard, 31 October.

Davis, G. F., McAdam, D., Scott, W. R. \& Zald, M. N. 2005, Social Movements and Organization Theory, Cambridge University Press, Cambridge. https://doi.org/10.1017/CBO9780511791000

Della Porta, D. 2007, The Global Justice Movement: Cross-national and Transnational Perspectives, Paradigm Publishers, Hardon. https://doi.org/10.4324/9781315634418 
U T S

e PRE S S
Department of Foreign Affairs and Trade, n.d., 'Australia's Uranium Export Policy, http://dfat.gov.au/internationalrelations/security/non-proliferation-disarmament-arms-control/policies-agreements-treaties/Pages/australias-uraniumexport-policy.aspx [Accessed 2 August 2018].

Dougherty, E.A. 2011, 'Commentary: Memories of the Future: the Poetry of Sadako Kurihara and Hiromu Morishita,' War, Literature and the Arts, vol. 23, nos. 1-2. Online, available: https://www.wlajournal.com/wlaarchive/23 1-2/ dougherty.pdf [Accessed 10 November 2020].

Edgington, D.W., 1984 'Some Urban and Regional Consequences of Japanese Transnational Activity in Australia,' Environment and Planning A, vol. 16: 1021-1040.https://doi.org/10.1068/a161021

Eyerman, R. \& Jamison, A. 1998, Music and Social Movements: Mobilizing Traditions in the Twentieth Century, Cambridge University Press, Cambridge. https://doi.org/10.1017/CBO9780511628139

Falk, J., Green, J. \& Mudd, G. 2006, 'Australia, Uranium and Nuclear Power,' International Journal of Environmental Studies, vol. 63, no. 6: 845-857. https://doi.org/10.1080/00207230601047131

Global Conference for a Nuclear Power Free World, 2012, 'Post Conference Announcement,'16 January. Online, available: http://npfree.jp/global-conference1/english [Accessed 2 August 2018].

Graeber, D. 2002, ‘The New Anarchists,' New Left Review, vol. 13: 61-73.

Gundjeihmi Aboriginal Corporation, 2011, 'Mirarr Resolve Against Uranium Mining Strengthened by Fukushima', 7 April. Online, available http://www.mirarr.net/library/mirarr-resolve-against-uranium-mining-strengthened-byfukushima [Accessed 1 June 2020].

Hayakawa, A. 2012, 'Translation as Politics: The Translation of Sadako Kurihara's War Poems,' Méthodologie de la Recherche en Traductologie: Applications, vol. 25, no 1: 109-131. https://doi.org/10.7202/1015349ar

Hindmarsh, R. \& Priestley, R. (eds) 2015, The Fukushima Effect: A New Geopolitical Terrain, Routledge, London. https:// doi.org/10.4324/9781315737041

Hintjens, H. 2000, 'Environmental Direct Action in Australia: The Case of Jabiluka Mine,' Community Development Journal, vol. 35, no. 4: 377-390. https://doi.org/10.1093/cdj/35.4.377

Iacobelli, P., Leary D. and Takahashi, S. (eds) 2016, Transnational Japan as History: Empire, Migration and Social Movements. Palgrave Macmillan. https://doi.org/10.1007/978-1-137-56879-3

Itō T. 2004, Nihon ga hakai suru sekai isan: Nihon no genpatsu to Ōsutoraria uran kōzan [The World Heritage Japan is Destroying: Japanese Nuclear Power and Australian Uranium Mining], Fūbaisha, Nagoya.

Jones, C.F., Loh, S.-L. \& Satō, K. 2013, 'Narrating Fukushima: Scales of a Nuclear Meltdown,' East Asian Science, Technology and Society, vol. 7, no. 4: 601-23. https://doi.org/10.1215/18752160-2392860

keb1974 2013, Australian Uranium Fueled Fukushima, video recording, YouTube, viewed 4 November 2020, https:// youtu.be/mqM1GZuILGA.

Kansteiner, W. 2002, 'Finding Meaning in Memory: A Methodological Critique of Collective Memory Studies,' History and Theory, vol. 41, no. 2: 179-97. https://doi.org/10.1111/0018-2656.00198

Mackie, V. 2015, 'Fukushima, Hiroshima, Nagasaki, Maralinga,' The Asia-Pacific Journal: Japan Focus, vol. 13, no. 6 iss. 5. Online, available: http://japanfocus.org/-Vera-Mackie/4281/article.html [Accessed 1 June 2020].

Mackie, V. \& Crozier-De Rosa, S. 2019, Remembering Women's Activism, Routledge, Abingdon. https://doi. org/10.4324/9780429456022

McCausland, S. 1999, 'Leave it in the Ground: The Anti-Uranium Movement in Australia, 1975-82' PhD thesis, University of Technology Sydney. 
U T S

e PRES S
Morris-Suzuki, T. 2000, 'Anti-Area Studies,' Communal/Plural, vol. 8, no 1: 9-23. https://doi. org/10.1080/13207870050001439

Nakamura K. 2011, 'Abunai hon, abunai ishi: Ōsutoraria ni totte no Nihon to uran to midori no ari' [Dangerous Books, Dangerous Stones: Japan, Uranium and the Green Ants from the Australian perspective], Sekai, June: 164-171.

Nuclear Energy Agency and the International Atomic Energy Agency, 2006, Uranium 2006: Forty Years of Uranium Resources, Production and Demand in Perspective - 'The Red Book Retrospective', NEA No. 6096

O’Brien, J. 2003, 'Canberra Yellowcake: The Politics of Uranium and How Aboriginal Land Rights Failed the Mirarr people,' Journal of Northern Territory History, vol. 14: 79-91.

Piccini, J. 2016, Transnational Protest: Australia and the 1960s, Palgrave Macmillan, London. https://doi. org/10.1057/978-1-137-52914-5_1

Reitan, R. 2012, 'Theorizing and Engaging the Global Movement: From Anti-Globalization to Global Democratization,' Globalizations, vol. 9, no 3: 323-335. https://doi.org/10.1080/14747731.2012.682364

Renwick, N. \& Walton, D. 1992, 'Australian-Japanese Peace Movement Relations: Australian Perspectives,'Japanese Studies, vol. 12, no. 3: 111-23. https://doi.org/10.1080/10371399208521896

Rigney, A. 2018, 'Remembering Hope: Transnational Activism Beyond the Traumatic,' Memory Studies, vol. 11, no. 3: 368-380. https://doi.org/10.1177/1750698018771869

Ross, M. 2011, 'Fukushima Stokes Fears on Hiroshima Anniversary,' ABC Nerws Online, 7 August. Online, available http://www.abc.net.au/news/2011-08-06/hiroshima-day-rally/2827182 [Accessed 12 June 2018].

Routledge, P. 2013, 'Activist Ethnography and Translocal Solidarity,' Insurgent Encounters: Transnational Activism, Ethnography, and the Political, (eds.) J. S. Juris \& A. Khasnabish. Duke University Press, Durham: 250-268. https://doi. org/10.1215/9780822395867-011

Sibatani A. 1977, 'Genpatsu keikaku wa nai keredomo uran yushutsu ni hantai undō: Ōsutoraria kara no Hōkoku,' Asahi Jānaru, 25 February: 80-84.

Smile with Kids 2019, Facebook post, 22 July. Online, available: https://www.facebook.com/smilewithkids [Accessed 1 June 2018].

Starr, A. 2000, Naming the Enemy: Anti-Corporate Movements Confront Globalization, Zed Books, London.

Styczek, U. M. 2010, 'A-bomb Victim, Kurihara Sadako: The Transformation from Anarchist Poet to Peace Essayist,' Kenritsu Hiroshima Daigaku Ningenbunkagakubu Kiyō, vol. 5: 107-119.

Sundholm, J. 2011, 'Visions of Transnational Memory,' Journal of Aesthetics and Culture, vol. 3, no 1: 1-5. https://doi. org/10.3402/jac.v3i0.7208

Tsūshōsangyōshō shigen enerugii chō kōeki jigyōbu genshiryoku hatsuden ka, ed, Genshiryoku hatsuden binran [Nuclear Power Generation Handbook], 1987 edn. Tokyo: Denryoku shinpōsha, 1987.

Tsunekawa, K. 2018, 'Radioactive Contamination and Japan's Foreign Relations,' in Aftermath: Fukushima and the 3.11 Earthquake, (eds) Y. Tsujinaka \& H. Inatsugu. Kyoto University Press and Trans Pacific Press, Kyoto and Balwyn North, 2018: 382-400. https://doi.org/10.1007/978-981-15-7368-2

Van der Linden, M. 2017, Transnational Labour History: Explorations, Routledge, London. https://doi. org/10.4324/9781315235721

Walsh, J.P. \& Ungson, G.R. 1991, 'Organizational Memory,' Academy of Management Review, vol. 16, no 1: 57-91. https://doi.org/10.5465/amr.1991.4278992 
Wiemann, A. 2019, 'Making Memory by Dissociating the Past from the Present: Narratives of Movement Intellectuals of the Post-Fukushima Protest Cycle in Japan,' International Quarterly for Asian Studies, vol. 50: 157-170. https://doi. org/10.11588/iqas.2019.1-2.10344

Workers Bush Telegraph 2012, 'Bris Action: Japanese Reactors Must Stay Off-line,' 24 June. Online, available: http:// workersbushtelegraph.com.au/2012/06/24/bris-action-japanese-reactors-must-stay-off-line/ [Accessed 28 June 2012].

World Nuclear Association, 2019, Japan’s Nuclear Fuel Cycle. October. Online, available: https://www.world-nuclear.org/ information-library/country-profiles/countries-g-n/japan-nuclear-fuel-cycle.aspx [Accessed 17 February 2020].

Yoneyama, L. 1999, Hiroshima Traces: Time, Space, and the Dialectics of Memory, University of California Press, Berkeley and Los Angeles. https://doi.org/10.1525/9780520914896

Yoshioka, H. 2011, Genshiryoku no shakaishi: sono Nihonteki tenkai, new edition, Asahi Shimbunsha Shuppan, Tokyo.

Yoshioka, T. 2012, 'Together, For a Future without Nuclear Power,' in Global Conference for a Nuclear Power Free World: Conference Program.

Zwigenberg, R. 2014, Hiroshima: The Origins of Global Memory Culture, Cambridge University Press, Cambridge. https:// doi.org/10.1017/CBO9781107775442 